\section{Vesna Bosanac}

Prehrana sportaša, obrt za savjetovanje o prehrani

Donja Lomnica

vesna@prehranasportasa.com

Ljiljana Nanjara

Veleučilište "Marko Marulić"

Knin

ljnanjara@veleknin.hr
DOI $10.32458 /$ ei.26.5

UDK 392.8(497.5-3Zagora)"195" 641.1:392.8](497.5-3Zagora)

Stručni rad

Primljeno: 29. travnja 2021.

Prihvaćeno: 23. lipnja 2021.

\title{
Svakodnevna prehrana u Dalmatinskoj zagori pedesetih godina 20. stoljeća
}

- Po uzoru na opisivanje tradicionalne prehrane u različitim dijelovima Hrvatske, u ovom će se radu prikazati prehrana žitelja Dalmatinske zagore 50-ih godina prošloga stoljeća. Analizirat će se učestalost konzumiranja pojedinih skupina namirnica te prehrambene navike ondašnjega stanovništva. Rad naglašava nutritivnu vrijednost neprerađenih namirnica i njihovu korist za zdravlje te ukazuje na važnost njihove što češće zastupljenosti u prehrani modernog čovjeka.

Ključne riječi: Dalmatinska zagora, selo, tradicijska prehrana, prehrambeni običaji, hranidbena vrijednost

\section{UVOD}

U ranijim radovima o tradicijskoj prehrani na području Hrvatske vjerno su prikazane prehrambene navike i običaji u pojedinim dijelovima Hrvatske, kao npr. Baranji, varaždinskom kraju, Silbi, Olibu, Cresu i dr. te utjecaj gospodarstva, prometa, društvenih i povijesnih odrednica, kulture i religije na odabir namirnica i pripremu jela (Kašpar 1981.; Lazarević 1985.; Somek-Machala 1992.; Muraj 1997.). S obzirom na to da prije nisu obrađene karakteristike prehrane žitelja Dalmatinske zagore 50-ih godina 20 . stoljeća, ovaj rad obrađuje tu temu. Osim što se osvrće na svakodnevnu prehranu i na običaje vezane uz pripremu namirnica, također želi naglasiti nutritivni aspekt tradicijske prehrane.

Cjelovitiji pregledi tradicijske prehrane u Hrvatskoj sa specifičnostima pojedinih područja izborom namirnica, njihovim načinima pripreme, odabirom posuđa i pribora, 
običajima i sl. dani su u radovima etnologinja Aleksandre Muraj (1998.; 2001.) te Nives Rittig-Beljak i Mirjane Randić (2006.). Radovi upućuju na neujednačenost prehrane na teritoriju današnje Hrvatske odnosno na vidljivu razliku prehrambenih običaja i navika žitelja nizinske, planinske te primorske Hrvatske s otocima.

Dalmatinska zagora smještena je na jugu Republike Hrvatske, u kontinentalnom, pretežito ruralnom, brdsko-planinskom dijelu Splitsko-dalmatinske i Šibensko-kninske županije. Razvila je svoje specifične prehrambene značajke koje se ogledaju kako u odabiru namirnica i vrsti jela, tako i u načinima njihove pripreme i prigodama konzumiranja.

Prometna izoliranost te klima, nerijetko karakterizirana oštrim zimama praćenima snijegom i ledom, loša kvaliteta same zemlje koja se obrađivala, slaba obrazovanost stanovništva i sl., imali su jak utjecaj na prehrambene navike žitelja ovoga dijela Dalmacije. Nepostojanje rashladnih uređaja u lancu opskrbe i prodaje te u domaćinstvima bio je glavni razlog suženoga izbora namirnica (prvenstveno ribe te svježega voća) koji je istodobno određivao načine njihova konzerviranja (npr. sušenje mesa).

Upravo je loša prometna povezanost s priobaljem utjecala na slabu prisutnost morske ribe i maslinova ulja na jelovniku žitelja Dalmatinske zagore te to predstavlja značajni odmak od mediteranske prehrane. S druge strane, baziranje prehrane na žitaricama i povrću, uključujući i mahunarke, te konzumiranje orašastih plodova, kako je to bio običaj u Dalmatinskoj zagori, karakteristike su mediteranske prehrane.

Na prehranu stanovništva Hrvatske značajno su utjecale političke prilike (kao npr. dugotrajna vladavina Turaka) te religija, što se ogleda u planiranju prehrane prema vjerskim blagdanima.

Odabir namirnica i jela bio je uvelike sezonskoga karaktera, što je svakako ograničavalo dovoljan unos mikronutrijenata i drugih zaštitnih tvari. Imajući u vidu navedeno, za pretpostaviti je da prehrana spomenutoga razdoblja u Dalmatinskoj zagori ne bi udovoljavala sadašnjim kriterijima uravnotežene i raznolike prehrane te preporukama koliko često konzumirati meso, ribu i svježe voće, kako je to navedeno u "Normativima za prehranu učenika u osnovnoj školi" (NN 146/2012: 7).

S druge strane, sezonske bi namirnice, u prvom redu voće i povrće, neprerađene žitarice, uključujući i one koje su, nažalost, iščezle s jelovnika modernoga čovjeka, neizostavno trebale činiti osnovu današnje prehrane s obzirom na to da doprinose zdravlju i smanjenju rizika od bolesti krvožilnoga sustava, šećerne bolesti tipa II, nekih vrsta raka i sl. Upravo zbog toga svrha ovoga istraživanja i rada je bila istražiti karakteristike tradicijske prehrane Dalmatinske zagore te uz to istaknuti nutritivnu vrijednost i pozitivan učinak na zdravlje lokalno uzgojenih, neprerađenih namirnica.

\section{ISPITANICI I METODE}

Tijekom 2019. godine, a s ciljem prikupljanja podataka o prehrambenim navikama žitelja Dalmatinske zagore 50-ih godina 20. stoljeća, razgovaralo se s 50 osoba rođenih tijekom 20-ih, 30-ih i 40-ih godina prošloga stoljeća u Dalmatinskoj zagori, a 
koje su u promatranom razdoblju ondje i živjele. Ispitanici su bili osobe oba spola (no pretežito žene), različiti po obrazovanju i socioekonomskom statusu. Rad obuhvaća ispitanike s cijeloga prostora Dalmatinske zagore, sela Lećevicu, Ljubostinje, Vinovo Donje, Ogorje, Golubić, Smolonje, Slimu, Slivno, Čistu Malu, Danilo, Visoku, Zadvarje, Žagrović, Stankovce, Golubić, ${ }^{1}$ Prgomet, Proložac, Dugobabe, Brnaze, Planjane, Nevest, Šestanovac, Ljubitovicu, Prugovo, Čavoglave, Neorić, Muć, Obrovac pokraj Sinja, Nova Sela, Sutinu, Dolac, Mariće i Čvrljevo te gradove Imotski, Knin, Sinj i Vrliku.

U istraživanju je korištena anketa s 22 otvorena pitanja. Odnosila se na odabir namirnica i načine njihove pripreme tijekom različitih godišnjih doba, vjerskih blagdana, gospodarskih aktivnosti te obiteljskih i društvenih okupljanja. Kao predložak za sastavljanje ankete poslužio je rad "Seoska prehrana u Baranji” (Somek-Machala 1992.).

Ispitanici su tijekom anketiranja živjeli u svojim domovima ili u domovima za starije osobe. Do ispitanika koji su obitavali u svojim domovima došlo se osobnim poznanstvima. Ispitanici iz domova za starije osobe odabrani su uz pomoć i angažman radnih terapeutkinja zaposlenih u spomenutim ustanovama. Kriterij odabira bilo je dobro mentalno zdravlje te njihova spremnost i volja za razgovor s ispitivačima. U ovom radu obradili su se odgovori koji se odnose na svakodnevnu prehranu. Izostavljeni su oni koji obrađuju prehranu tijekom posebnih obiteljskih događaja i blagdana jer izlaze iz okvira teme ovoga rada.

\section{REZULTATI}

Pedesetih godina prošloga stoljeća prihodi žitelja Dalmatinske zagore dolazili su od posla u klasičnom smislu te poljoprivrede (stočarstva i zemljoradnje). Zaposlene osobe su se bavile poljoprivredom nakon posla te vikendom.

\section{UČESTALOST KONZUMIRANJA OBROKA I OSNOVNE NAMIRNICE}

U Dalmatinskoj zagori se, prema navikama, koje su u znatnoj mjeri određivale i financijske mogućnosti, a prema kazivanju ispitanika, dnevno konzumiralo jedan (doručak ili ručak) do četiri obroka (doručak, ručak i večeru te jutarnju ili popodnevnu užinu, marendu).

Prema kazivanju ispitanika rodom iz sela Visoka pokraj Unešića četiri puta dnevno su jeli i radnici koji bi radili na polju. Za razliku od doručka, koji je bio manji i skromniji, marenda je u Dalmatinskoj zagori bila konkretniji obrok. Često su je jela djeca kada bi, prema kazivanju ispitanika, ogladnila. Navika marendavanja se zadržala do današnjih dana te predstavlja konzumiranje toploga obroka tijekom pauze na poslu.

Iz skupine žitarice, proizvodi od žita i zamjene, standardne škrobaste namirnice bile su pura (palenta), kruh i krumpir. Jele su se svakodnevno, cijele godine. Od povrća se

1 Stankovci i Golubić se nalaze u Zadarskoj županiji. 
uglavnom, tijekom cijele godine jeo kupus, svježi i kiseli. Prema sezoni, na jelovniku su bili još blitva, kelj, repa, mrkva, raštika i kapula (crveni luk). Često su se pripremale i mahunarke, prvenstveno grah i slanutak. Kad god je za to bilo prilike, brale su se samonikle zeljaste biljke, divlje zelje ili mišancija (npr. komorač, tušt, žutenica, kopriva). Voće se jelo prvenstveno u sezoni dozrijevanja. Većinom su to bile šljive, kasne smokve - poljarice, jabuke, dunje, rane kruške (petrovke), trešnje, višnje te breskve, no samo u ponekim krajevima Dalmatinske zagore.

Meso se nije jelo svaki dan. Njegovu prisutnost u prehrani ondašnjih žitelja Dalmatinske zagore uvelike su ograničavale financijske mogućnosti. Kada je za to bilo prilike, jela se svinjetina, kozletina, govedina, janjetina i ovčetina te piletina. Meso se često sušilo. Žiteljima Dalmatinske zagore mlijeko i kiselo mlijeko (od koza, krava i ovaca) bile su važne namirnice. Sira nije bilo u izobilju. Riba se jela vrlo rijetko, nekoliko puta godišnje. S obzirom na tradiciju svinjogojstva, u Dalmatinskoj zagori se od masnoća uglavnom koristila svinjska mast. Nasuprot tomu, maslinovo ulje je bilo rijetko dostupno.

Od bezalkoholnih pića, najčešće se konzumirala voda, a od alkoholnih vino i rakija. Karakteristična slastica u Dalmatinskoj zagori svakako su uštipci neutralnoga, više slanoga okusa.

\section{RASPRAVA}

\section{ŽITARICE, PROIZVODI OD ŽITA I ZAMJENE}

Žitarice (npr. ječam i pšenica), proizvodi od žita (primjerice tjestenina) i zamjene (kao što je krumpir), čovjeku su glavni izvor energije. Tako se pura s mlijekom jela često prije odlaska na rad upolje. Ljudima sa strane, koji bi došli pomoći oko poljoprivrednih radova, bi se pripremila pura zalivena mašću ili poprženom slaninom. Jedna ispitanica iz Sutine, čija je obitelj bila izuzetno siromašna, uz anketu je dodala: "Kad nisi ima ništa drugo, uzeja bi grumen pure. Ne volin ti je ja. Podsjeća me na tešku glad i neimaštinu.“

Kruh se u Dalmatinskoj zagori pravio od pšeničnoga, mješavine pšeničnoga i ječmenoga brašna te kukuruza (kuruzovnica), a kao kvasac se koristio komadić tijesta od prethodnoga zamjesa. Pekao se ispo' peke (tj. saća, kako peku zovu u Imotskoj krajini) ili u špakeru na drva, no ne svaki dan. Jeo se skoro uvijek za doručak. Nerijetko bi se radila popara kada bi se kruh, star nekoliko dana, namočio u vruću vodu. Čak i u slučajevima siromaštva, kada odrasli članovi obitelji nisu doručkovali, djeci, koja bi ujutro gonila blago (vodila krave, ovce ili koze) na pašu, dao bi se komad kruha.

Značaj žitarica u prehrani ovoga dijela Dalmacije spominje još početkom 20. stoljeća u svom djelu "Poljica" Frano Ivanišević navodeći "U koga nije žita i kruva, tomu slabo prolazi godina, taj pati glad." (Ivanišević 1987: 96)

U Dalmatinskoj zagori su se pripremale i kaše, jela slična puri, no po konzistenciju su bile nešto rjeđe. Kuhale su se od različitih žitarica: pšenice, ječma i kukuruza. Moglo bi se reći da je svaki zaseok kašu kuhao na svoj način. U Čvrljevu se za večeru često pripremala bijela kaša (od pšenice) s maslacem. U Imotskom se ona zvala maslokaša. U 
Smolonjima "iznad" Omiša kuhala se kaša od ječma i krumpira začinjena s malo ulja, u Stankovcima se ona radila od kukuruzne krupice i poprženoga luka (na maslinovom ulju, tko ga je imao), u Marićima u Šibenskom zaleđu se jela kaša od kuruza i ječma.

Obično su se žitarice kuhale na vodi, no to nije bilo pravilo. U Brnazama su imućnije obitelji kuhale pšeničnu kašu na mlijeku. Moglo bi se reći da je bila poput današnjega griza na mlijeku. Osim u obliku kaše, u sezoni (ljeti i u jesen) se u Dalmatinskoj zagori jeo kukuruz u klipu i to pečeni ili kuhani. Krumpir se pripremao na različite načine: kuhao se sam ili u varivu, pekao ucilo u lugu, ispod peke izrizan na pola (često za večeru). S obzirom na to da je zauzimao značajno mjesto u prehrani, bio je važan izvor vitamina $C$, posebno u doba ograničene konzumacije svježega voća i povrća.

Nadalje, često su se zimi jeli grā i jari grā: grah i slanutak. Diljem Dalmatinske zagore se radila jota (varivo od kiseloga kupusa i graha). Za razliku od današnjega vremena, tjestenina se jela rijetko. U Prugovu se radila sitna tjestenina za juhu. U Kninu i okolici se pravila pašta od šenice. U Imotskoj krajini su se radile tajadele, a u okolici Sinja lazanje koje su se kuhale i posluživale kao prilog. Pandan je to današnjoj kuhanoj tjestenini. Ovi specifični nazivi bili su prisutni u Trogiru krajem 18. stoljeća. I tamo su se pripremale tagliatele i lazanje (obično s mladim bobom), dok su se špageti i makaroni kombinirali s umacima, najčešće umakom od rajčica (Celio Cega 2008: 288).

Postojale su i razlike u pripremi tjestenine. Dok se u Čavoglavama ona znala pripremati sa svježim i kiselim kupusom uz dodatak masti, u imućnijim obiteljima u Prgometu i Stankovcima se kuhana domaća tjestenina začinjala i drugom raspoloživom masnoćom (npr. maslinovim uljem). Za nas danas je to vrlo jednostavno jelo, no u ondašnje vrijeme je, u mnogim dijelovima Dalmatinske zagore, ono bilo luksuz te se serviralo samo tijekom nekih svečanosti i nedjeljom.

Nasuprot tomu, kupovna tjestenina u obliku kakvu je danas poznajemo se jela rijetko, najčešće kao pašta-fažol (varivo s grahom i tjesteninom). U Neoriću pokraj Muća i Obrovcu u Sinjskoj krajini se ovo jelo pripremalo tijekom žetve. Manistra s kapulom i krumpirom jela se tijekom žetve u Novim Selima pokraj Omiša, ali i u Sutini pokraj Muća. U Slivnom se za jematvu jelo varivo od ječma i manistre.

Iako je Dalmatinska zagora bio poprilično izoliran kraj, ipak je između nje i priobalja bilo razmjene običaja i navika. Može se to zahvaliti gospodarstvu (poljoprivrednoj proizvodnji i trgovini), ženidbama i sl. Tako etnologinja Fani Celio Cega u svojoj knjizi "Svakidašnji život grada Trogira od sredine 18. stoljeća do sredine 19. stoljeća" spominje kako njegovi stanovnici posjeduju obradivo zemljište u Unešiću, Prgometu, Ljubitovici, Labinu, Boraji, Sitnom, Sratoku i Radošiću (Celio Cega 2005: 75).

Povezanost trogirskoga područja s Dalmatinskom zagorom ogleda se i u drugim područjima života. Svjedoče tomu izrazi poput sukanac (pokrivač), šotana (suknja), dota (miraz), bičve (čarape), balote (boće) (Celio Cega 2005: 78, 137, 172) koji se i danas koriste u Dalmatinskoj zagori.

Nadalje, žitelji dijela Dalmatinske zagore gajili su prijateljske veze sa stanovnicima Trogira. Prema navodu iz djela spomenute autorice, jedna je bogata trogirska obitelj 
prijateljevom sinu iz Sinja za krizmu poklonila zlatnu medalju (Celio Cega 2005: 135). Živa je bila trgovina pa su za vrijeme pazarnih dana stanovnici Zagore dolazili u Trogir prodavati svoje proizvode, kupovati različite potrepštine i družiti se "Na Travarici bi igrali narodna kola pjevajući svoje tradicionalne pjesme uz pratnju gusli ili mišnica." (Celio Cega 2005: 170) Uvelike se prakticirala i robna razmjena. Tako jedna ispitanica iz Unešića opisuje kako je kao djevojčica od 12, 13 godina sa starijim ukućanima odlazila u Šibenik mijenjati poljoprivredne proizvode za druge potrepštine, od kojih je posebno bila vrijedna sol.

Trogirani su sa stanovnicima Dalmatinske zagore održavali i intelektualne veze. Tako su u 18. stoljeću za savjet oko izgradnje kazališta kontaktirali jednoga arhitektu iz Knina, koji je u ondašnje vrijeme bio jedan od nekolicine školovanih arhitekata na našim područjima (Celio Cega 2005: 161).

Zanimljivo je kazati kako su, prema fotografiji u spomenutoj knjizi autorice Fani Celio Cega, krajem 19. stoljeća žene u Trogiru vezivale kosu u pletenicu te ju motale oko zatiljka dodirujući rub tjemena. Isti je običaj saplićanja/splićanja kose u jednu ili dvije pletenice i njihovim motanjem oko glave bio i u Dalmatinskoj zagori.

\section{POVRĆE}

Konzumiranje povrća imalo je 50-ih godina 20. stoljeća u Dalmatinskoj zagori izražen sezonski karakter. Kupus se, bilo slatki ili kiseli (sorte glavaš), jeo gotovo svaki dan. Najčešće tijekom glavnoga obroka. Kuhao se čak i za svinjokolju. Kiseli kupus pripremao se u Dalmatinskoj zagori na salatu, kuhao se i jeo sam ili kombinirao s purom i suhim mesom. "Uvik je bilo te nesritne kupusine. I petkon i svetkon", opisuje čestu prisutnost ovoga povrća ispitanik iz Potravlja. Obilje kupusa u prehrani spominje i Frano Ivanišević govoreći o prehrani u Poljicima navodeći: "Kupus je poglavita 'ràna od zeleni u Poḷicin, ima ga, brate, po svinselin.” (Ivanišević 1987: 101) Osim kupusa, kroz cijelu godinu su se konzumirali raštika, repa, mrkva, blitva i kapula (crveni luk). Često su se jele i samonikle zeljaste biljke, divlje zelje ili mišancija (npr. komorač, tušt, žutenica, kopriva...). I Frano Ivanišević je spominjao konzumiranje divljega zelja u Poljicima navodeći: “...eto stari' žena, koje su na siromašnu topragu, uzmu britvicu u ruku i uputu se priko pola, da uparaju struk zeleni i trave za zalogaj. Nike se jidu i sirove, a nike kuvaju ili začinu kvasinon, ulen i osolu se. To su trave žutenica, dušnica, kostrič, bobovina, špinak." (Ivanišević 1987: 104)

Zelje, blitva, kelj i druge kupusnjače su se kuhali lešo te kombinirali s purom, kruhom i krumpirom. Ova pozitivna navika zadržala se u Dalmaciji i danas.

U proljeće su se u Dalmatinskoj zagori brale šparoge, dok se u jesen išlo u gljive. I dan danas se skupljaju samo šampinjoni. Iako vjerojatno postoje i druge jestive gljive, žitelji ovoga djela Hrvatske ih ne poznaju. Šampinjoni su izvor prehrambenih vlakana te vitamina B1, C i D. Istraživanja na životinjama pokazuju kako ove gljive pomažu snižavanje visoke koncentracije glukoze, masnoća i kolesterola u krvi. Također, pozitivno djeluju na rad jetre (Gupta et al. 2018: 15-20). 
Postoje i neke specifičnosti vezane uz povrće u Dalmatinskoj zagori. Tako se u Docu pokraj Omiša grašak kuhao samo u dane posta. U Čvrljevu se tijekom žetve kuhalo fažolete (zelene mahune) ili biže (grašak). Hrana se nije bacala. Kada bi priteklo kuhane repe ili zelja, sutradan bi se pomiješali s poprženim lukom i jeli za doručak, prije polja. Iako je ondašnja gastronomija Dalmatinske zagore bila skromna, ipak je iznjedrila neke delicije koje su danas naše zaštićeno kulturno dobro. Tako iz Omiškoga zaleđa potječe soparnik (jelo od pšeničnoga tijesta s nadjevom od luka i blitve). Pripremao se u posebnim prigodama, npr. za žetvu. Danas je tradicija njegove pripreme oživjela te je to neizostavno jelo u ponudi mnogih ugostiteljskih objekata: od zalogajnica do najprestižnijih restorana.

Nažalost, svjedoci smo nedovoljne prisutnosti zelenoga lisnatog povrća u današnjoj svakodnevnoj prehrani. Iskustveno su znali naši stari kako su brojne njegove blagodati za zdravlje čovjeka. Povrće poput blitve, kelja i raštike važan je prirodni izvor folata u prehrani. Folat je vitamin B skupine koji ima brojne funkcije u organizmu. Pomaže u normalizaciji krvnoga tlaka, razvoju kognitivnih sposobnosti djece, sprječavanju proliferacije stanica raka te pojave i liječenja megaloblastične anemije. Njegov adekvatan unos doprinosi pravilnom razvoju neuralne cijevi nerođenoga djeteta. Nadalje, zeleno lisnato povrće dobar je izvor karotenoida, mangana, željeza, vitamina E i folata, betalaina te fenolnih tvari antioksidativnoga djelovanja. Upravo zato ono ima protuupalno djelovanje te sprječava dijeljenje stanica raka (Yadav et al. 2013: 709-711).

Prema kazivanju jedne ispitanice, u njezinoj obitelji, mlijeka i sira nije bilo u izobilju. "Mlika bi ti baba donila kad si bija bolestan. Volila sam se razbolit jer san znala, doće baba", pripovijeda. Ipak ta starija gospođa nikad nije imala lomove ili druge probleme s kostima. Svakako je svoj doprinos zdravlju kostiju dala česta prisutnost zelenoga povrća i samonikloga bilja u prehrani. Ono je 50-ih godina prošloga stoljeća, kada je u Dalmatinskoj zagori vladala oskudica, doprinosilo kvaliteti obroka i zadovoljavanju nutritivnih potreba stanovništva.

Znanstvena literatura pokazuje pozitivnu vezu između konzumiranja zelenoga povrća i zdravlja kostiju. Blitva, kupus, raštika i sl. izvor su kalcija, magnezija, kalija te vitamina C i K - nutrijenata koji doprinose gustoći koštane mase (Muñoz-Garach et al. 2020: 4-7). Štoviše, zeleno povrće kao koristan izvor kalcija, u slučaju smanjene prisutnosti ili izostavljanja mlijeka i mliječnih proizvoda iz prehrane, te njegovu ulogu u očuvanju zdravlja kostiju, spominje i znanstvena literatura (Mangels 2014: 470S-471S).

Moglo bi se kazati kako redovito konzumiranje zelenoga lisnatog povrća, uz tjelesnu aktivnost, nesumnjivo doprinosi adekvatnoj izgradnji kostiju u djetinjstvu i mladosti te kasnijem očuvanju njihove gustoće. Svakako bi stoga ovo povrće trebali više cijeniti i češće ga uključiti u jelovnik. Dodatni razlog za češće konzumiranje zelenoga lisnatog povrća je njegova niska energetska vrijednost što doprinosi rješavanju sve prisutnijega problema pretilosti.

Na istoj strani u borbi protiv pretilosti su i mahunarke što mogu zahvaliti značajnoj prisutnosti ugljikohidrata i bjelančevina te malom sadržaju masti. S obzirom na oskudnu prisutnost namirnica životinjskoga podrijetla (u prvom redu mesa) u prehrani 
Dalmatinske zagore sredinom prošloga stoljeća, dobrodošle su bile kombinacije mahunarki i žitarica (npr. varivo od graha i ječma). Mahunarke i žitarice međusobno se nadopunjuju svojim aminokiselinskim sastavom. S obzirom na to da su aminokiseline građevni elementi za stanice, komplementarnost mahunarki i žitarica bila je od velikoga nutritivnog značaja za ondašnje prilike u Dalmatinskoj zagori. Da su mahunarke bile jedne od glavnih namirnica kazuje i Frano Ivanišević navodeći: "Sočivo iza kupusa jest u Poḷicin poglavita 'rana." (Ivanišević 1987: 111)

Mahunarke sadrže folat, cink, kalcij i sl. (Erbersdobler et al. 2017: 138) Tu je i željezo, no ono je, iz mahunarki kao namirnica biljnoga podrijetla, lošije iskoristivo od onoga iz mesa ili ribe. Poznato je kako vitamin C poboljšava njegovu apsorpciju. Nalazi se, među ostalim, i u kupusu, a upravo se jota; varivo od kiseloga kupusa i graha, često zimi jela u Dalmatinskoj zagori. Nedvojbeno je to tada doprinosilo pozitivnom statusu željeza u organizmu.

Mahunarke sadrže popriličnu količinu prehrambenih vlakana, kako topljivih tako i onih netopljivih. Netopljiva vlakna doprinose funkciji crijeva. Topljiva vlakna usporavaju probavljanje škroba što doprinosi normalizaciji visoke koncentracije glukoze u krvi i dužoj sitosti.

Mahunarke zaštitno djeluju i protiv raka debeloga crijeva. Naime, dio prisutnih ugljikohidrata neprobavljen dospijeva u debelo crijevo gdje ga razgrađuju probiotičke bakterije. Stvaraju se masne kiseline kratkih lanaca. Među njima se nalazi maslačna kiselina koja sprečava razvoj raka debeloga crijeva. Uz to, i fitinska kiselina iz mahunarki pokazuje antikancerogeno djelovanje te zaštitno djeluje protiv raka dojke i debeloga crijeva. Valja dodati kako su mahunarke od koristi i za zdravlje kostiju. Njihove bjelančevine pomažu apsorpciju kalcija iz hrane. Uz to, mahunarke podupiru zdravlju prostate. Može se to zahvaliti prisutnosti vlakana te izoflavona, saponina, likopena i fitosterola čije sinergističko djelovanje doprinosi njezinoj zaštiti (Singh et al. 2017: 859-867).

Još jedno, danas nepravedno zapostavljeno povrće, svakako je repa. Osim što se konzumira kao povrće, repa je pomoć u liječenju artritisa i gihta, bolesti jetre te želučanih tegoba (uključujući kronični gastritis). Znanstvena istraživanja pokazuju kako repa, poput drugih vrsta povrća iz porodice kupusnjača, igra zapaženu ulogu u sprječavanju pojave različitih vrsta raka (Paul et al. 2018: 19-24).

I dok su prije 70-ak godina u Dalmatinskoj zagori, luk i češnjak često bili prisutni u prehrani ondašnjih žitelja, danas se oni, zbog društvenih razloga, uvelike izbjegavaju (Kolovrat 2006: 113). Nažalost je tomu tako. Zeleni listovi mladoga luka bogat su izvor vitamina C i karotenoida, a tu su i aromatične tvari sa sumporom koje djeluju protiv bakterija i gljivica. Štoviše, listovi pokazuju izraženiju antioksidativnu aktivnost od same lukovice.

Nadalje, luk pokazuje protuupalna svojstva, pomaže probavu te doprinosi sniženju koncentracije masnoća i glukoze u krvi. Uz to, ima antikancerogeno, antiaterosklerotsko i antitrombotičko djelovanje. Djeluje i kao antibiotik, diuretik, laksativ te olakšava astmatične tegobe. Pomaže reguliranje koncentracije glukoze i masnoća u krvi (Bahram-Parvar i Lim 2017: 293-297). 
Češnjak je jedna od najčešće korištenih biljaka u narodnoj medicini Dalmatinske zagore. Uzima se kako bi se spriječila prehlada. Štiti protiv šećerne bolesti i bolesti srca, smanjuje nastajanje ugrušaka krvi, snižava krvni tlak, kolesterol i šećer u krvi. Njegova česta prisutnost u jelovniku smanjuje rizik za nastajanje različitih vrsta raka: usta, želuca, debeloga crijeva i prostate (Shang et al. 2019: 2-6).

Kao što je prije spomenuto, u Dalmatinskoj zagori često su se kao povrće jele samonikle lisnate biljke: kopriva, tušt, maslačak i sl. Kopriva je našim precima u proljeće bila dobrodošli izvor vitamina C. Upravo u prijelaznom razdoblju iz zime u ljeto opada imunitet pa su nutrijenti koji ga jačaju od iznimne koristi. Osim toga, u koprivi su željezo, kalij (koji je neophodan za normalnu funkciju srca), vitamini A, K, D, B1, B2, pantotenska kiselina, folat te brojne fitokemikalije poput flavonoida. U narodnoj se medicini kopriva uspješno primjenjuje u sprječavanju i liječenju anemije, probavnih tegoba, tuberkuloze, reumatskih tegoba, visokoga krvnog tlaka, hunjavice, prehlade te bubrežnih kamenaca. Sa svojim lektinima pokazala se korisnom i u liječenju povećanja prostate. Kopriva je bogata antioksidansima koji štite stanice čovjeka od oksidativnoga stresa. Blagotvorna je prema jetri što su potvrdila i znanstvena istraživanja. Nadalje, kopriva, sprječava dijeljenje stanica raka, posebno raka vrata maternice i dojke. Konzumiranje koprive smanjuje koncentraciju kolesterola u krvi i sprječava pojavu ateroskleroze (Tabasum et al. 2018: 25-26).

Maslačak sadrži željezo, a tu je i vitamin C te je sasvim sigurno da maslačak jača imunitet i sprječava pojavu anemije. Sadrži beta-karoten antioksidativnoga djelovanja čija prisutnost obnavlja kožu oštećenu aktivnošću slobodnih radikala nastalih sunčanjem. Osim toga, maslačak još sadrži kalcij i kalij zbog čega doprinosi regulaciji krvnoga tlaka. Odavno se u narodnoj medicini koristi kao poticaj mokrenju te protiv upala i reumatskih tegoba. Zahvaljujući prisutnim vlaknima pomaže rad crijeva, a njegov pikantan okus koji dijelom potječe od taraksacina, potiče apetit.

Aktivne tvari maslačka učinkovite su protiv virusa gripe, a uz to imaju antioksidativno djelovanje (Daniel et al. 2021: 18). U Dalmatinskoj zagori se i danas zimi priprema salata od kuhanih korijena maslačka.

U ovom području, iznimno je na cijeni tušt. Kombinira se s blitvom. Zavidnoga je nutritivnoga sastava. Štoviše, bogatiji je mikronutrijentima od mnogih vrsta povrća. Primjera radi, u tuštu je čak pet puta više alfa-linolenske kiseline nego u špinatu, a beta-karotena ima više nego u bilo kojoj vrsti zelenoga povrća. Tu su još vitamin C, riboflavin, niacin, piridoksin te mineralne tvari kalij, magnezij i željezo. Iz tušta su k tomu izolirani flavonoidi, steroli, alkaloidi, terpenoidi i dr. Činjenica je kako je tušt bogat vlaknima, a siromašan energijom, čime doprinosi regulaciji šećera, masnoća i kolesterola u krvi te mršavljenju. Također štiti integritet perifernih krvnih žila. Ova samonikla biljka sadrži alfa-linolensku omega-3 masnu kiselinu koja podupire rast i razvoj, jača imunitet te dokazano djeluje protiv nastajanja raka (Srivastava et al. 2021: 4-6).

Prije spomenuta šparoga simbol je Dalmacije i specijalitet njezine Zagore. Frano Ivanišević u svojoj knjizi "Poljica” piše: “Čobanice beru u paši i sparog, ali to je gospodsko 
jiće: ako mogu, prodadu popu ili učitelju ili pošalju u grad, da uvatu koju gàstu (novac) za svoje potribice." (Ivanišević 1987: 104)

Šparoga je namirnica niske energetske vrijednosti. Sadrži neznatnu količinu masti, a s druge strane obiluje vodom, vlaknima, vitaminima (npr. C, K, B1, folat i E) i mineralnim tvarima (magnezijem i kalcijem). Jača imunitet što može zahvaliti prisutnosti vitamina B2, cinka, selena i željeza te antioksidansa, među kojima se ističu rutin i kvercetin (Ku et al. 2018: 309).

Sve u svemu, navika konzumiranja povrća za ručak i večeru, koja je kod starije populacije Dalmatinske zagore prisutna još i danas, svakako je pozitivna odrednica raznolike prehrane.

\section{VoćE}

Vrste divljega i kultiviranoga voća određivali su klimatski uvjeti te su u sezoni dozrijevanja na jelovniku bile šljive, kasne smokve - poljarice, jabuke, dunje, rane kruške (petrovke), trešnje, višnje te breskve (ali samo u nekim krajevima, npr. u Čavoglavama). Dalmatinska zagora je poznata po uzgoju grožđa. Od grožđa se prvenstveno radilo vino. I, naravno, grožđe se jelo. Tijekom jematve se u Čvrljevu, Sutini i Prugovu uz grožđe jeo kruh i lešo krumpir.

Kako bi se što duže sačuvalo za jelo, ubrani zdravi i jedri grozdovi su se držali obješeni na hladnom mjestu (npr. u konabi) na šipki. Nakon berbe djeca bi zašla u vinograde gdje bi im slučajno nađeni neubrani grozdovi pričinjali veliko zadovoljstvo.

Trešnje i višnje su bile rijetkost te su slovile za delikatesu. Zimi su se jele suhe smokve. U Dalmatinskoj zagori uspijevaju bademi i orasi. Svojim nutritivnim sastavom (esencijalnim masnim kiselinama, vitaminima i mineralnim tvarima poput selena) često su dopunjavali prehranu stanovnika ovoga područja. Nosili su se upolje i jeli s kruhom. Konzumirali su se i plodovi samoniklih voćaka: oskoruše, kupine, drinjine, duda (murve), maginje i divlje šljive (u Imotskom ih nazivaju zerdelije, u Obrovcu pokraj Sinja srdelije, a u Prugovu arzelinke). S obzirom na to da su one samonikle, možemo biti sigurni da plodovi nemaju ostatke pesticida. Danas su one nažalost zanemarene i propadaju. U Dalmatinskoj zagori se voće nije konzerviralo kuhanjem i ukuhavanjem. Nisu se radili kompoti, džemovi i marmelade.

Jedan od simbola Dalmacije i Dalmatinske zagore svakako je smokva. U Zagori nema njezinih planskih nasada, već se stabla nalaze raštrkana pokraj kuća i u vinogradima. Smokve prirodno sadrže popriličnu količinu šećera pa su sigurno ljudima koji su radili na polju bile dobrodošli izvor energije. Osim toga, one su zanimljivoga mikronutritivnog sastava. Za razliku od većine voća, u njima je željezo koje doprinosi imunitetu te kalcij i magnezij. Osim toga, znanstvenici su pokazali kako se glavnina antioksidansa (polifenola i antocijanina) nalazi u koži smokve. Upravo su male smokve poljarice tanke jestive kože rasprostranjene u Dalmatinskoj zagori. Štoviše, u koži ljubičastih smokava, kojih također ima po vinogradima Dalmatinske zagore, antioksidansa je još i više. Jestivost kože smokve doprinosi unosu vlakana u organizam pa tako smokve 
doprinose normalizaciji koncentracije kolesterola, masnoća i šećera u krvi, zdravlju srca, normalnom radu crijeva te detoksikaciji (Kamiloglu i Capanoglu 2015: 524-531). Ne manje važna je i činjenica kako je ovo voće otporno na štetočine pa ga se rijetko tretira pesticidima.

Zimi su se štedljivo jele suhe smokve te je bilo povlašteno svako domaćinstvo koje ih je imalo. Suhe smokve prava su riznica fenola po kojima su poznati crno vino i zeleni čaj. One tako doprinose zaštiti od pojave raka jednjaka, dojke, prostate, jajnika i debeloga crijeva (Soni et al. 2014: 160-161). Može se sa sigurnošću reći kako je konzumiranje smokava snažno doprinosilo kvaliteti prehrane ondašnjih stanovnika Dalmatinske zagore.

Višnje su u Dalmatinskoj zagori posebno bile na cijeni. Izrazito su bogate antioksidansima. Sadrže ih više od trešanja. Zahvaljujući tomu, pomažu ublažavanje oštećenja stanica i slabljenja funkcije organa. Posebno to dolazi do izražaja u starijoj životnoj dobi. Prisutnost ovoga voća u prehrani pomaže zdravlje gušterače (koja proizvodi inzulin). Također, višnje djeluju protuupalno, sudjeluje u normalizaciji koncentracije šećera u krvi i općenito smanjuju rizik za pojavu šećerne bolesti (Cásedas et al. 2016.).

Zbog siromaštva i ograničenoga izbora voća u prehrani, trešnjama su se u Dalmatinskoj zagori posebno veselila djeca. Brojne su dobrobiti trešanja na zdravlje. Znanstvenici su pokazali kako trešnje jačaju djelovanje antioksidansa koji štite masti prisutne u plazmi od oksidacije. Također, smanjuje se degradacija mišićnoga tkiva što je važno zbog zaštite zdravlja lokomotornoga sustava. Trešnje su bogate antocijaninima, kvercetinom, kalijem, vlaknima, vitaminom C, karotenoidima i melationinom. Ove hranjive tvari visoke biološke vrijednosti pokazuju preventivno djelovanje protiv nastajanja cijeloga niza zdravstvenih tegoba poput raka, bolesti srca i krvnih žila, upalnih bolesti, Alzheimerove i šećerne bolesti (Faienza et al. 2020: 2-7).

Od divljega voća svakako valja spomenuti drijenak. "Zdrav k'o dr'en”, uzrečica je kojom opisujemo ljude koji pucaju od zdravlja. Vjerojatno je to zbog toga što je drijenak, izuzetno izdržljiva i nezahtjevna voćka. Drinjine, kako u Dalmatinskoj zagori zovu njegove plodove, bogate su vitaminom C. Značajan je i sadržaj izrazito aktivnih antocijana koji imaju antioksidativno i protuupalno djelovanje. U narodnoj se medicini drinjine koriste za jačanje zdravlja probavnoga sustava. Posebno su učinkovite protiv proljeva (Kaya i Koca 2021: 155-159).

\section{MESO, RIBA, JAJA I SIR}

Ovo je skupina namirnica različitoga podrijetla, a koje su glavni izvori visokokvalitetnih bjelančevina u prehrani. Meso sadrži željezo i cink u lako iskoristivom obliku te vitamine $\mathrm{B}_{6} \mathrm{i}_{12}$ (kojih nema u namirnicama biljnoga podrijetla).

Meso je 50-ih godina prošloga stoljeća bilo iznimno cijenjena namirnica. Imati meso u kući bilo je stvar prestiža i luksuz nedostupan svima. Konzumiralo se onoliko koliko su financijske mogućnosti dopuštale. Od mesa se, uglavnom, ovisno o godišnjemu dobu, konzumirala svinjetina, kozletina, govedina, janjetina i ovčetina te piletina. Obično 
se jelo dva puta tjedno: četvrtkom i nedjeljom te za blagdane i obiteljske proslave. Tako se janjetina pekla u Čvrljevu, Kninu i Čavoglavama za žetvu i jematvu. Kod onih siromašnijih su se jeli slanina, krumpir i zelen. Neke obitelji su, prema kazivanju ispitanika, jele meso samo dva puta godišnje.

U Dalmatinskoj zagori se meso najčešće jelo kuhano pa bi se usput napravila i juha. Prema kazivanju ispitanika iz Šestanovca, juha se kuhala često za radnike i rodbinu koji bi došli pomagati u žetvi. Može se reći kako je juha ostala neprikosnoveno predjelo diljem Dalmatinske zagore i mnogima bez nje "nema ručka".

Često su domaćinstva držala prasad, najčešće samo jedno pa je suhomesnatih proizvoda moralo doteć za cijelu godinu. U glavnini su se pršut, plećka i pečenica (sušena leđa bez kosti) nosili dokturima i drugim ljudima od ugleda, dok je obitelj jela lošije kategorije mesa. Suhomesnati su se proizvodi koristili štedljivo, često samo da jelo malo zamiriše. Tako su se diljem Zagore (npr. u Muću, Ogorju i Docu) kuhala suha rebra u varivu od kupusa i raštike, a čvarci su se jeli s purom. I Frane Ivanišević kazuje kako se u Poljicima kupus začinjao slaninom; "truni grc slanine u kupus, eto najlipše začine." (Ivanišević 1987: 99)

Suha rebra s dinstanim (pirjanim) kiselim kupusom pripremali su se u Dalmatinskoj zagori kao malo bolji ručak za jematvu. Ako bi se radnicima u polje nosio kuhani ručak, koristio se bronzin (jednostavni metalni lonac s dvije rupe o koje bi se, kao ručka, okvačila deblja žica). Radile su se divenice (kobasice). Njih se jelo podjednako štedljivo. U Prgometu su se pripremale za večeru nakon berbe grožđa.

Zanimljivo je reći da su se u Trogiru krajem 18. stoljeća radile male kobasice - luganiges rižotom od iznutrica. Kuriozitet je da se u ovom gradu u to vrijeme uvozila salama (Celio Cega 2008: 288), vjerojatno iz Italije. Naravno, bogatije obitelji Dalmatinske zagore mogle su sebi priuštiti pršut. On se uz sir jeo tijekom radova u polju (žetve, jematve i sl.). U Planjanima kraj Drniša bi se prilikom otakanja vina okupili ljudi (iz obitelji i prijatelji) pa bi uz mlado vino jeli pršut i sir.

Zanimljivo je reći kako u Dalmatinskoj zagori ne postoji naziv za svinjokolju. Tako se ne pita: “Kada će kod tebe biti svinjokolja?" već se pita: "Ka' ćeš klat'?” U dane svinjokolje se pripremala đigerica (jetrica) na saft i pura, a također su se često jetrica i drugo meso (npr. file - svićica) pekli na gradele (na roštilju). Jele su se i žmare (čvarci). U Čvrljevu se za klanje jela slanina i gulaš s krumpirima. Krvavice su se radile od svinjske krvi, kukuruzne krupice, papra, soli i masnoga tkiva. Nakon punjenja u oprana crijeva, one su se kuhale pa potom sušile i dimile. U Šestanovcu su se u dane klanja jele krvavice i sudžuk, kobasice. Naziv je ostao od vremena Turaka. U Nevestu u Šibenskoj zagori su se jele krvavice, tripice (fileki), varivo s ječmom i sl. Tijekom svinjokolje i jematve u drniškom i sinjskom kraju se kuhala goveđa juha.

Tijekom anketiranja ispitanici su se redovito prisjećali zajedništva među rodbinom i prijateljima. Ljudi su se međusobno pomagali i bili na usluzi jedni drugima. To se primjećivalo i tijekom svinjokolje. Susjedima koji nisu imali svoje svinje bi se dao komad pečenice, slanine i sl. 
Osim svinjetine, sušila se i kozletina pa je tako u Čistoj Maloj jelo od sušene kozletine i boba bio specijalitet. Jela se i bravetina (suha ovčetina) i to obično ujesen. Većinom zbog neimaštine ljudi su prije 70-tak godina bili više okrenuti namirnicama koje su se mogle pribaviti lovom i skupljanjem. Diljem Zagore su se skupljali i jeli puževi te lovili zečevi, a u Danilu su se čak ježevi držali za specijalitet.

Važnost ribe i drugih plodova mora u prehrani ogleda se u prisutnosti esencijalnih aminokiselina i masnih kiselina, vitamina i mineralnih tvari od kojih je potrebno spomenuti jod zbog njegove uloge u sprječavanju gušavosti i kretenizma. Zbog sadržaja omega-3 masnih kiselina, preporučljivo je ribu konzumirati dva puta tjedno, od toga barem jedan put plavu. Riba se prije 70-tak godina konzumirala prema mogućnostima i dostupnosti. Bilo je to vrlo rijetko. U Imotskoj se krajini za vrijeme posta najčešce konzumirala pržena srdela, a na Badnjak i Veliki petak se pripremao bakalar, obično na bijelo. Nasuprot tomu, u Visokoj kraj Drniša se bakalar pripremao s rižom. Kuriozitet je da su bakalar u nekim obiteljima u Prugovu kuhali isključivo muškarci. Usporedbe radi, i u Trogiru se pripremao bakalar na bjanko dok se gulašu s bakalarom dodavalo suho grožđe (Celio Cega 2008: 288).

Osim srdela, jele su se još girice, bugve te skuše. Obično su se frigale (pržile) na ulju. Riba se znala i peći na gradele. Riba se u Sinj dovozila kamionom, a u Zadvarje su je ribari, prema kazivanju jedne ispitanice, "svako jutro na leđima donosili iz Baške Vode". U Perković se riba dovozila vlakom. Tamo se ona jela češce jer se oskudijevalo mesom.

U Šestanovcu su se tijekom jematve u vinogradu jele slane srdele i pilo vino. Treba napomenuti da se u naseljima oko rijeke Vrljike i Imotskih jezera, jela i slatkovodna riba poput šarana, masnice, plotice te cijenjena imotska gaovica. U Vrljici se lovila autohtona pastrva i rakovi, koji su danas gotovo nestali. I u Cetinskoj krajini se uz morsku ribu jela i slatkovodna riba: uklija, šaran, pastrva i klen te rakovi. Važno je spomenuti da je riba koja se jede s kostima (srdele, girice...) izvor kalcija u prehrani, što je u slučaju skromnijih financijskih mogućnosti svakako od značajne koristi.

U skupinu namirnica bogatih bjelančevinama spadaju i jaja. Dobar su izvor cinka te vitamina $A, E, D$ i $B_{12}$. Jaja su se pripremala na razne načine, većinom kuhana i pržena. Prva su se, prema kazivanju ispitanika iz Žagrovića pokraj Knina, obično konzumirala tijekom radova u polju. U Ljubostinjama pokraj Unešića su se jaja pripremala $u$ lugu. Kuhala su se utvrdo i umeko ( $u$ sorbulu), pržila sa slaninom, krumpirima, šparogama, gljivama ili kapulom, od kuhanih jaja se radila salata i sl. Meko kuhana jaja su se običavala jesti tako da se u njih toćao (umakao) kruh. U Čvrljevu bi se frigana jaja davala isključivo bolesnicima i gostima što je bila velika čast.

Specijalitetom su se držala sirova jaja pomiješana s prošekom. Davala su se kao okrepa bolesnima i djeci koja su bila slabija. Ipak, valja reći da jaja nije bilo tijekom cijele godine pa su se u oskudici davala samo djeci. Također, neka su domaćinstva jaja isključivo prodavala "za sol, sapun i petrolej", kako neki kažu.

Sir je, 50-ih godina 20. stoljeća, žiteljima Dalmatinske zagore bio posebno na cijeni i siromašnija domaćinstva, koja nisu imala ovce, koze ili krave ga sebi često nisu mogla 
priuštiti. Pravio se od kravljega, kozjega i ovčjega mlijeka kao i njihove kombinacije. Zanimljivo je spomenuti da je prije 70-ak godina on još uvijek bio i roba za razmjenu.

Pojedini krajevi Dalmatinske zagore su imali i svoje specifičnosti. Tako se u Golubiću radila skuta (sir od sirutke), u Prgometu traveni sir od kiseloga mlijeka, a u Vinovu Donjem i Čvrljevu sir iz mišine. U Smolonjima se, za radnike na polju, pohao mladi sir. Pofrigani (prženi) mladi sir preliven jajima bio je posebni užitak tijekom žetve u Čvrljevu.

Od sira, jaja, malo soli i skorupa (vrhnja izdvojenoga na površini mlijeka) se u Stankovcima radio prisnac. Frano Ivanišević spominje prisnac kao "pecivo koje se učini od brašna i mlada sira" (Ivanišević 1987: 110). U Prgometu se ujutro prije odlaska u vinograd jela pura sa sirom ili mlijekom. Sir je bio dobrodošla namirnica tijekom rada u polju, npr. tijekom trganja (berbe grožđa) kada nije bilo mogućnosti kuhati ručak.

\section{MLIJEKO, JOGURT I SRODNI FERMENTIRANI PROIZVODI}

U Dalmatinskoj zagori važno su mjesto u prehrani imali mlijeko i kiselo mlijeko, od koza, krava i ovaca. Zanimljivo je reći kako su u nekim krajevima, kao u selu Danilu, obično mlijeko pile samo žene, a u Prugovu se mlijeko pilo na slamku (grančicom Božjega drveta). Kao zamjena za slatko i kiselo mlijeko se u danima oskudice pilo modro mlijeko (mlijeko razrijeđeno vodom). Posebna delicija bila je varenika, ukuhano punomasno mlijeko bogato skorupom (izdvojenim vrhnjem). Kao što je prije spomenuto, mlijeko se jelo s kruhom i purom. S mlijekom se radila bijela kava koja se obično pila za doručak. To je navika koja je u Dalmaciji, barem među starijom populacijom, ostala do današnjih dana. Pila se i sirutka.

\section{MASTI}

Uzgoj svinja jedna je od važnijih odrednica Dalmatinske zagore, a koja je utjecala na gastronomiju. Shodno tomu, u pripremi jela se koristila većinom svinjska mast. Maslinovo ulje se koristilo u dijelovima Zagore koji su bili bliže moru, npr. u Smolonjima i Slimi pokraj Omiša, a u drugim krajevima vrlo rijetko. Kako kažu ispitanici iz Ogorja Gornjega i Golubića, maslinovo ulje se "mirilo na kapi”. Iznimka su obitelji čiji su članovi, prema kazivanju ispitanika iz Slivnoga pokraj Imotskoga ili Ljubitovice pokraj Trogira, odlazili brati masline u Živogošće odnosno Vinišce i za svoj rad bili plaćeni u ulju. Naravno, maslinovo ulje su sebi mogla priuštiti bogatija domaćinstva.

Osim masti, u Dalmatinskoj zagori se prilikom pripreme jela koristio i loj. Njime se vrlo često ujutro u Obrovcu iznad Cetine začinjala kaša pripremljena od pšeničnoga brašna. Prema mogućnostima konzumirao se i maslac (zvao se maslo) od kravljega i ovčjega mlijeka. Posebno je njegova prisutnost vidljiva u obiteljima koje su bile bogate te imale svoje blago. Tako je jedna ispitanica spomenula da su oni pržili fritule na svome maslu.

Skorup je bio iznimna poslastica. Suncokretovo i sojino ulje se koristilo rjeđe. U Novim Selima pokraj Omiša se sojino ulje koristilo u pripremi soparnika i uštipaka. U skupinu masti spada i orašasto voće. U Dalmatinskoj zagori oduvijek uspijevaju orah i bajam 
(badem) koji su svojim sadržajem esencijalnih masnih kiselina, mineralnih tvari i vitamina doprinosili kvaliteti ondašnje prehrane. Orasi i bademi često su uz kruh bili izvor energije kada se radilo u polju ili vinogradu.

\section{PIĆA}

Od bezalkoholnih pića najčešće se konzumirala voda, a od alkoholnih vino i rakija. Crno vino cijenjeno je zbog antioksidansa koje sadrži. Jedan od njih je kvercetin koji štiti od pojave raka i bolesti srca. Tu je i resveratrol koji pomaže detoksikaciju organizma i snižavanje koncentracije šećera u krvi. Snižava se i količina masnoća te kolesterola. Također, smanjuju se upalni procesi u organizmu. Alkohol u umjerenoj količini povisuje koncentraciju tzv. dobroga kolesterola, sprječava zgrušavanje krvi i smanjuje količinu homocisteina u tijelu, a koji loše djeluje na srce (Amor et al. 2018: 1-7).

Rakiju su, prema kazivanju ispitanika iz Dugobaba, rijetko pile žene. Kada su je pile, bilo je to u svrhu liječenja želučanih tegoba. Likeri su se radili, no to je bilo vrlo rijetko. Naime, rijetki su znali recepturu njihove izrade. U iznimnim se prigodama pio prošek.

Prema pričanju ispitanika iz Muća, djeca su ponekad bila u prilici popiti sok. U nekim područjima, kao u Čistoj Maloj, se djeci davala bevanda (vino s vodom). Kao osvježenje se u Danilu pila razrijeđena kvasina (vinski ocat). U nekim područjima Dalmatinske zagore se radio voćni sirup. U Muću, Šestanovcu, Prološcu Donjem i Lećevici se tako radio sirup od višanja. U Vrlici su se pili svježi voćni sokovi. Zanimljivo je da je u Brnazama u to doba jedan privatni poduzetnik pravio i flaširao gazirani sok - šabezo (od njem. Chabeso). Napitak izvorno potječe iz Njemačke. U našim krajevima se afirmirao između dva svjetska rata, a proizvodio do 60-ih godina prošloga stoljeća (Miholek 2016.). Sastojci su mu bili voda, ekstrakt arome voća, mliječna kiselina te šećer (Neumann et al. 1915.).

\section{SLASTICE}

Izbor slastica tijekom promatranoga razdoblja bio je skroman i one su se konzumirale rijetko. Najčešće su se u posebnim prigodama pekli (pržili) uštipci od tijesta malo gušćega od onoga za palačinke, no nisu bili slatki. Držali su se za specijalitet samo zato što se nisu jeli često već obično nedjeljom i za blagdane. Osim njih, u mnogim su se krajevima Dalmatinske zagore radile fritule, posebice za Badnjak, što je tradicija koja se zadržala do danas. No, i u ovom segmentu običaja su prisutne razlike.

U Danilu, u Šibenskom dijelu Zagore djeci su se gotovo svakodnevno radili prspaji (lepinje od dizanoga tijesta pržene na ulju ili masti). Još jedan specijalitet su bile palačinke. Pripremale su se diljem Zagore: u zaseoku Marići pokraj Šibenika, u Vinovu Donjem pokraj Trogira i drugdje. U Obrovcu pokraj Sinja se za vrijeme žetve kuhala riža na mlijeku, kao velika počast radnicima u polju, bilo da se radi o članovima obitelji, rodbini, prijateljima ili za novac angažiranim ljudima. 
Bogatije obitelji su sebi mogle priuštiti luksuz. Tako se u jednom dobrostojećem domaćinstvu u zaseoku Bulići pokraj Muća svake subote radio kolač s orasima. Prema mogućnostima, u Imotskoj krajini su se znala peći i peciva s bademima ili orasima, koja su se premazivala žumanjkom i šećerom kako bi dobila poželjnu zlatnu boju. Treba spomenuti inovativnost djece iz bogatijih obitelji ovoga kraja koja je bombone "izrađivala" izlijevanjem rastopljenoga šećera u snijeg, u godinama kada ga je bilo. Siromašniji nisu mogli "bacat' šećer tek tako". Ipak, zaključno se može prenijeti kazivanje jedne ispitanice koja je rekla kako se "u to doba nisu radili nikakvi današnji kolači”. Neka domaćinstva su imala pčele pa su medom obogaćivala svoju prehranu.

\section{ZAKLJUČAK}

Prehranu Dalmatinske zagore 50-ih godina prošloga stoljeća uvelike je određivao sezonski karakter prisutnosti namirnica pa se može reći da pojedine skupine namirnica (npr. voće) cijele godine nisu bile zastupljene svakodnevno u prehrani.

Ipak, s nutricionističkoga aspekta, pojedine ondašnje navike u prehrani ne bi bilo loše primjenjivati i danas. Ponajprije bi od koristi u suvremenoj prehrani bila tadašnja umjerenost u jelu i piću, češće konzumiranje sezonskih, neprerađenih ili minimalno prerađenih namirnica, uzgojenoga voća i povrća (u prvom redu onoga iz porodice kupusnjača), divljega voća (kupina, duda i divljih šljiva) te jela od cjelovitih žitarica (npr. ječma) i mahunarki.

Žitelji Dalmatinske zagore 50-tih godina prošloga stoljeća gotovo nisu ni konzumirali polugotovu i gotovu hranu u obliku u kojem je danas poznajemo. Konzumiranje mesa i mesnih proizvoda bilo je manje, što je ograničavalo unos kolesterola i zasićenih masnih kiselina. Pohvalne su to značajke ondašnje prehrane čija bi afirmacija sigurno imala pozitivan učinak na zdravlje modernoga čovjeka. Osim toga, valjalo bi potaknuti današnje ljude na korištenje vlastite zemlje i samostalan uzgoj hrane kad god je to moguće. Rezultiralo bi to češćim boravkom u prirodi i redovitom, svrsishodnom tjelovježbom.

Prihvaćanje pozitivnih, a sada nažalost već iščezlih navika ondašnjega čovjeka, uvelike bi doprinijelo smanjenju pretilosti, šećerne bolesti te bolesti krvožilnoga sustava u današnjem društvu. Važnost redovite tjelesne aktivnosti i kvalitetne prehrane ne može se nikada dovoljno naglasiti. Na nju treba podsjećati iz dana u dan te vjerujemo da će i ovaj rad tomu doprinijeti.

\section{ZAHVALA}

Zahvaljujemo svim osobama koje su izdvojile svoje vrijeme i s radošću pristupile anketiranju. Veliko hvala radnim terapeutkinjama Doma za starije i nemoćne osobe Split te Doma za starije i nemoćne osobe "Lovret" u Splitu na neizmjernoj ljubaznosti i ogromnoj pomoći oko organiziranja anketiranja. 


\section{LITERATURA I IZVORI:}

AMOR, Souheila, CHÂLONS, Pauline, AIRES, Virginie i Dominique DELMAS. 2018. "Polyphenol Extracts from Red Wine and Grapevine: Potential Effects on Cancers". Diseases 6/4. https://www.mdpi.com/2079-9721/6/4/106 (pristup 17.2.2021.).

BAHRAM-PARVAR, Maryam i Loong-Tak LIM. 2018. "Fresh-CutOnion: A Review on Processing, Health Benefits, and Shelf-Life". Comprehensive Reviews in Food Science and Food Safety 17/2: 290-308. https://onlinelibrary.wiley.com/doi/full/10.1111/1541-4337.12331 (pristup 20.1.2021.).

CÁSEDAS, Guillermo, LES, Francisco, PILAR GÓMEZ-SERRANILLOS, Maria, SMITH, Carine i Víctor LÓPEZ. 2016. "Bioactive and functional properties of sour cherry juice (Prunus cerasus)". Foodand Function 7: 4675-4682. https://pubs.rsc.org/en/content/articlehtml/2016/ fo/c6fo01295g (pristup 10.1.2021.).

CELIO CEGA, Fani. 2005. Svakidašnji život grada Trogira od sredine 18. do sredine 19. stoljeća. Split: Književni krug.

CELIO CEGA, Fani. 2008. "Kuhinja, blagovanje, prehrana u plemićkoj palači u 18. st. - ideja za novi stalni postav u Muzeju grada Trogira”. Etnološka istraživanja 12/13: 285-291. https://hrcak.srce.hr/37029 (pristup 12.12.2020.).

DANIEL, Imaobong, MATHEW, K.N. i P.L. JOHN. 2021. "Evaluation of Vitamin Contents, Antioxidant and Antimicrobial Actvities of Different Leaf Extracts of Taraxacum officinale (Dandelion)". Journal of Complementary and Alternative Medical Research 13/2: 13-26. https://www.journaljocamr.com/index.php/JOCAMR/article/view/30220 (pristup 10.3.2021.).

ERBERSDOBLER, Helmut, BARTH, Christian i Gerhard JAHREIS. 2017. "Legumes in human nutrition. Nutrient content and protein quality of pulses". Ernährungs Umschau 64/9: 134-139. DOI: 10.4455/eu.2017.034 (pristup 5.2.2021.).

FAIENZA, Maria Felicia, CORBO, Filomena, CAROCCI, Alessia, CATALANO, Alessia, CLODOVEO, Maria Lisa, GRANO, Maria, WANG, David Q.-H., D'AMATO, Gabriele, MURAGLIA, Marilena, FRANCHINI, Carlo, BRUNETTI, Giacomina i Piero PORTINCASA. 2020. "Novel insights in health-promoting properties of sweet cherries". Journal of Functional Foods 69:103945. https://www.sciencedirect.com/science/article/pii/S1756464620301699 (pristup 11.1.2021.).

GUPTA, Sachin, SUMMUNA, Baby, GUPTA, Moni i Sudheer Kumar ANNEPU. 2018. "Edible Mushrooms: Cultivation, Bioactive Molecules, and Health Benefits". U: Bioactive Molecules in Food. Reference Series in Phytochemistry. Mérillon JM., Ramawat K., ur. Cham: Springer, str. 1-33. https://link.springer.com/referenceworkentry/10.1007\% 2F978-3-319-54528-8_86-1 (pristup 15.12.2020.).

IVANIŠEVIĆ, Frano. 1987. [1906.]. Poljica. Split: Književni krug.

KAMILOGLU, Senem i Esra CAPANOGLU. 2015. "Polyphenol Content in Figs (Ficus carica L.): Effect of Sun-Drying”. International Journal of Food Properties 18/3: 521-535. https:// doi.org/10.1080/10942912.2013.833522 (pristup 11.1.2021.).

KAŠPAR, Libuše. 1981. "Seoska prehrana varaždinskog kraja”. Godišnjak gradskog muzeja 6/6: 113-124. https://hrcak.srce.hr/192514 (pristup 10.1.2021.). 
KAYA, Zeliha i İlkay KOCA. 2021. "Health Benefits of Cornelian cherry (Cornusmas L.)". Middle Black Sea Journal of Health Science 7/1: 154-162. https://dergipark.org.tr/en/pub/ mbsjohs/issue/61963/824473 (pristup 8.7.2021.).

KOLOVRAT, Miroslav. 2006. “Čudesni svijet magije - češnjak”. MESO: Prvi hrvatski časopis o mesu VIII/3: 113-116. https://hrcak.srce.hr/index.php?show=clanak\&id_clanak_jezik=34847 (pristup 2.2.2021.).

KU, YangGyu, BAE, Jong Hyang, NAMIEŚNIK, Jacek, BARASCH, Dinorah, NEMIROVSKI, Alina, KATRICH, Elena i Shela GORINSTEIN. 2018. "Detection of Bioactive Compounds in Organically and Conventionally Grown Asparagus Spears". Food Analytical Methods 11: 309-318. https://medicine.ekmd.huji.ac.il/en/research/shelag/Publications/2018\%20 Food\%20Anal\%20Meth.pdf (pristup 15.11.2020.).

LAZAREVIĆ, Aleksandra-Sanja. 1985. "Tradicijska prehrana na otocima Silbi i Olibu - Pokušaj interdisciplinarnog pristupa". Etnološka tribina 15/8: 61-70. https://hrcak.srce. $\mathrm{hr} / 80266$ (pristup 10.1.2021.).

MANGELS, Ann Reed. 2014. "Bone nutrients for vegetarians". American Journal of Clinical Nutrition 100/1: 469S-475S. https://academic.up.com/ajcn/article/100/suppl_1/469S/4576666 (pristup 7.2.2021.).

MIHOLEK, Vladimir. 2016. “Šabesa”. Podravske širine. 10. kolovoza, https://podravske-sirine. com.hr/arhiva/3934 (pristup 8.1.2021.).

MINISTARTSVO ZDRAVLJA. 2012. "Normativi za prehranu učenika u osnovnoj školi". Narodne novine 146/2012. https://narodne-novine.nn.hr/clanci/sluzbeni/2012_12_146_3164. html (pristup 12.1.2021.).

MUÑOZ-GARACH, Araceli, GARCÍA-FONTANA, Beatriz i Manuel MUÑOZ-TORRES. 2020. "Nutrients and Dietary Patterns Related to Osteoporosis". Nutrients 12/7, 1986. https:// www.mdpi.com/2072-6643/12/7/1986 (pristup 8.1.2021.).

MURAJ, Aleksandra. 1997. "Za creskim stolom. Tradicijska prehrana u strukturi lokalne kulture”. Etnološka tribina 27/20: 145-210. https://hrcak.srce.hr/80754 (pristup 1.3.2021.).

MURAJ, Aleksandra. 1998. “Obrisi svakidašnjeg života”. U: Etnografija: svagdan i blagdan hrvatskog puka. J. Čapo Žmegač, A. Muraj, Z. Vitez, J. Grbić i V. Belaj, ur. Zagreb: Matica hrvatska, str. 23-150.

MURAJ, Aleksandra. 2001. "Prehrambene tradicije". U: Hrvatska tradicijska kultura na razmeđu svjetova i epoha. Z. Vitez i A. Muraj, ur. Zagreb: Institut za etnologiju i folkloristiku, str. 295-308.

NEUMANN, P.W., SCHOLL, A., SUTTHOFF, W., HEUSER G. i G. SONNTAG. 1915. „Obst, Beerenfrüchte und Fruchtsäfte”. Zeitschrift für Untersuchungder Nahrungs und Genußmittel 29: 99-103. https://doi.org/10.1007/BF02025622 (pristup 18.1.2021.).

PAUL, Swastika, GENG, Chang-An, YANG, Tong-Hua, YANG, Yong-Pingand i Jun CHEN. 2018. "Phytochemicaland Health-Beneficial Progress of Turnip (Brassicarapa)". Journal of Food Science 84/1: 19-30. https://pubmed.ncbi.nlm.nih.gov/30561035/ (pristup 18.1.2021.).

RITTIG-BELJAK, Nives i Mirjana RANDIĆ. 2006. Svijet hrane u Hrvatskoj. Zagreb: Etnografski muzej. 
SHANG, Ao, CAO, Shi-Yu, XU, Xiao-Yu, GAN, Ren-You, TANG, Guo-Yi, CORKE, Harold, MAVUMENGWANA, Vuyo i Hua-Bin LI. 2019. "Bioactive Compounds and Biological Functions of Garlic (Alliumsativum L.)”. Foods 8/7: 246. https://www.ncbi.nlm.nih.gov/ pmc/articles/PMC6678835/ (pristup 12.2.2021.).

SINGH, Balwinder, SINGH, Jatinder Pal, SHEVKANI, Khetan, SINGH Narpinder i Amritpal KAUR. 2017. "Bioactive constituents in pulses and their health benefits". Journal od Food Science and Technology 54/4: 858-870. https://www.ncbi.nlm.nih.gov/pmc/articles/ PMC5336453/ (pristup 14.12.2020.).

SOMEK-MACHALA, Božica. 1992. "Seoska prehrana u Baranji". Studia ethnologica Croatica 4/1: 141-151. https://hrcak.srce.hr/75754 (pristup 5.2.2021.).

SONI, Neha, MEHTA, Sanchi, SATPATHY, Gouri i Rajinder GUPTA. 2014. "Estimation of nutritional, phytochemical, antioxidant and antibacterial activity of dried fig (Ficus carica)". Journal of Pharmacognosy and Phytochemistry 3/2: 158-165. https://www. phytojournal.com/vol3Issue2/Issue_jul_2014/3-3-1.1.pdf (pristup 7.3.2021.).

SRIVASTAVA, Rajani, SRIVASTAVA, Vineet i Ajeet SINGH. 2021. "Multipurpose Benefits of an Underexplored Species Purslane (Portulaca oleracea L.): A Critical Review". Environmental Management. https://doi.org/10.1007/s00267-021-01456-z (pristup 8.7.2021.).

TABASUM, Fatima, BAZILA, Naseer i Zameer Syed HUSSAIN. 2018. "Stinging Nettle: A herb with tremendous pharmacological potential". International Journal of Unaniand Integrative Medicine 2/2: 24-28. https://www.unanijournal.com/articles/29/2-2-2-591. pdf (pristup 17.5.2021.).

YADAV, Ramesh Kumar, KALIA, Pitam, KUMAR, Raj i Varsha JAIN. 2013. "Antioxidant and Nutritional Activity Studies of Green Leafy Vegetables". International Journal of Agriculture and Food Science Technology 4/7: 707-712. https://www.ripublication.com/ ijafst_spl/ijafstv4n7spl_12.pdf (pristup 20.12.2020.). 